\title{
Analisis Pengaruh E-WOM, Online Review, dan Kualitas Informasi terhadap Minat Beli di Market Place Tokopedia
}

\author{
Julian Andrew, Rezi Erdiansyah \\ julian.915160076@stu.untar.ac.id, rezie@fikom.untar.ac.id
}

Fakultas Ilmu Komunikasi Universitas Tarumanagara

\begin{abstract}
As the people's shopping habits via online starts to emerge, the e-commerce industry in Indonesia has also developed. In 2018, it was noted that 11.9\% of Indonesian people were shopping online. However, in the midst of the vastness of online platforms with millions of items found in online storefronts, consumers need more information as their reference to arousing buying interest. As one of the biggest e-commerce players in Indonesia, Tokopedia provides features that enable sellers and consumers to exchange information regarding the items. In Tokopedia, prospective buyers can see electronic word of mouth messages, online reviews, and other additional information about the items that are known to be very influential in generating buying interest. This study uses a quantitative approach with an explanatory type in which the research seeks to find the effect of electronic word of mouth, online review, and the quality of information on buying interest of Jakarta students in Tokopedia ecommerce. The data collection technique used was purposive sampling by distributing questionnaires to 100 samples via online. Based on this research's results, it was found that electronic word of mouth, online review, and information quality affect buying interest of students in Jakarta by $46 \%$ while the other $54 \%$ were influenced by other factors not examined in this study.
\end{abstract}

Keywords: E-WOM, Information Quality, Online Review, Purchase Intentions, Tokopedia

\begin{abstract}
Abstrak
Seiring dengan munculnya kebiasaan berbelanja masyarakat melalui online, industri ecommerce di Indonesia pun turut berkembang. Pada tahun 2018, tercatat bahwa sebanyak $11,9 \%$ orang di Indonesia melakukan kegiatan belanja secara online. Namun, di tengah luasnya platform online dengan jutaan barang yang terdapat di etalase online membuat konsumen membutuhkan informasi yang lebih sebagai bahan referensi dalam menimbulkan minat beli. Tokopedia merupakan pelaku e-commerce terbesar di Indonesia menyediakan fitur-fitur yang memungkinkan penjual dan konsumen untuk menulis dan bertukar informasi seputar barang tersebut. Di dalam Tokopedia, para calon pembeli dapat melihat pesan electronic word of mouth, online review, dan informasi-informasi tambahan lainnya seputar barang-barang yang dijual yang diketahui sangat berpengaruh dalam memunculkan minat beli. Penelitian ini menggunakan pendekatan kuantitatif dengan jenis eksplanatif dimana penelitian berusaha menemukan pengaruh $e-W O M$, kualitas informasi, dan online review terhadap minat beli mahasiswa Jakarta pada e-commerce Tokopedia. Teknik pengumpulan data yang digunakan adalah purposive sampling dengan menyebarkan kuesioner kepada 100 sampel secara online. Penelitian menemukan bahwa electronic word of mouth, online review, dan kualitas informasi berpengaruh terhadap minat beli pada mahasiswa di Jakarta sebanyak 46\%, sedangkan 54\% dipengaruhi oleh faktor-faktor lain yang tidak diteliti pada penelitian ini.
\end{abstract}

Kata Kunci: E-WOM, Kualitas Informasi, Minat Beli, Online Review, Tokopedia 


\section{Pendahuluan}

E-commerce merupakan suatu kegiatan yang berhubungan dengan jual-beli barang yang menghubungkan penjual dan pembeli secara digital dengan menggunakan teknologi elektronik. Penggunaan e-commerce bertujuan untuk meningkatkan dan mengembangkan bisnis melalui sumber daya dan sarana elektronik sehingga diharapkan terjadi peningkatan laba bagi pelaku usaha. Fenomena ini akhirnya memicu munculnya berbagai e-commerce di Indonesia dengan menawarkan berbagai promo.

E-commerce di Indonesia yang pertama menerapkan sistem marketplace adalah Tokopedia. Marketplace dan e-commerce memiliki beberapa perbedaan yaitu marketplace dapt menjual berbagai macam produk dari berbagai penjual sedangkan $e$ commerce semata-mata menjual suatu produk hanya dari satu perusahaan dan hanya memiliki penjual tunggal. Tokopedia mempunyai dua tipe konsumen yaitu buyer dan seller yang menjadikan Tokopedia harus bersaing dengan e-commerce lainnya.

Melalui fenomena ini, biasanya masyarakat cenderung berperilaku melihat ulasan sebelum melakukan pembelian pada Tokopedia. E-WOM merupakan komunikasi dengan cara tertulis berupa pengalaman yang biasa bersifat tentang keunggulan produk dari pembeli dalam membeli suatu produk melalui teknologi elektronik.dan media elektronik. Keberadaan era digital tentunya memiliki peranan penting sehingga strategi marketing word of mouth yang dijalankan oleh e-commerce bisa berjalan lebih efektif dan menjaring lebih banyak pelanggan potensial dalam skala besar.

Melalui media elektronik komunikasi e-wom, konsumen dapat menerima informasi yang berhubungan dengan suatu jasa dan produk dari berbagai macam masyarakat dari yang mereka kenal dan mereka tidak kenal dan juga dari berbagai macam kota dan negara dengan pengalaman dalam membeli suatu produk dan jasa. (dalam Wijaya dan Paramita, 2014). Ketika ingin membeli sesuatu konsumen cenderung melihat dan mempertimbangkan pengalaman orang lain sebelum akhirnnya mengambil keputusan untuk membeli suatu barang atau jasa (Evans dan Mckee, 2010).

Pada saat ini proses pemasaran dinilai lebih efektif dengan menggunakan EWOM pada akun sosial media karna bisa digunakan oleh masyarakat luas. Dalam mengambil keputusan untuk membeli sebuah jasa, merk atau produk tertentu dapat dipengaruhi oleh E-WOM karna E-WOM menyediakan sebuah sarana yang luas. Media yang dipakai oleh E-WOM pun tidak ada batasannya (Rachmalica et.al., 2015). Media sosial yang sudah berkembang dengan pesat dan mempunyai pengaruh besar terhadap penggunanya mejadi salah satu cara electronic word of mouth untuk berkomunikasi. E-wom digunakan menjadi alat media untuk mendapatkan informasi dengan cepat dari berbagai pihak. Sebelumnya kita hanya bisa berhubungan dengan keluarga dan teman namun sekarang tidak lagi. Mayoritas para pengguna E-wom dapat mengakses sosial media dalam kehidupan sehari-hari. (Suwarduki et. al., 2016)

Informasi yang diperoleh dari internet dinilai lebih kredibel dari perusahaan web, serta lebih meyakinkan dan persuasif adalah alasan dari forum internet dapat menarik konsumen dan mempengaruhi konsumen untuk berkunjung. Mereka merasa informasi yang disediakan oleh suatu forum lebih dapat dipercaya karena sebagian besar memiliki pengalaman tentang produk atau jasa dan mernerima informa informasi dengan natural dan merekomendasikan karena memang sudah memiliki pengalaman tidak dimanipulasi. 
Melalui fenomena ini, biasanya masyarakat cenderung berperilaku melihat ulasan sebelum melakukan pembelian pada e-commerce. E-WOM merupakan komunikasi dengan cara tertulis yang berada di media elektronik yang memiliki hubungan dengan pengalaman pembeli dalam membeli suatu produk serta keunggulan produk tersebut melalui teknologi elektronik. Keberadaan era digital tentunya memiliki peranan penting sehingga strategi marketing word of mouth yang dijalankan oleh e-commerce bisa berjalan lebih efektif dan menjaring lebih banyak pelanggan potensial dalam skala besar.

Salah satu gambaran E-WOM yang berpacu pada konten buatan penggunanya yang diposting pada situs web pihak ketiga maupun situs online adalah Online Customer Review. Salah satu faktor yang paling mempengaruhi seseorang dalam menentukan keputusan melakukan pembelian atau tidak adalah online customer review (Farki dkk.,2016). Sarana ulasan untuk memberikan umpan balik (feedback) tersebut merupakan strategi pemasaran word of mouth di era elektronik saat ini. Untuk bertahan dalam sebuah persaingan bisnis, perusahaan harus memiliki keunggulan sehingga mampu menarik keputusan pembelian konsumen. Berdasarkan pada hal tersebut, penulis tertarik untuk mengangkat penelitian dengan judul "Analisis Pengaruh E-WoM, Online Review. dan Kualitas Informasi terhadap Minat Beli di Market Place Tokopedia."

\section{Metode Penelitian}

Dalam penelitian ini menggunakan metode kuantitatif eksplanatif. Metode penelitian kuantitatif eksplanatif yaitu penelitian yang mempunyai maksud untuk menganalisis hubungan-hubungan antara satu variabel dengan variabel lainnya atau bagaimana mempengaruhi variabel lainnya (Umar, 2005:36). Eksplanatif memiliki tujuan untuk menjelaskan suatu generalisasi sampel terhadap populasinya atau menjelaskan hubungan, perbedaan, pengaruh satu variabel dengan variabel lainnya (Bungin, 2013, p.38). Metode penelitian kuantitatif eksplanatif sebagai penelitian yang menjelaskan hubungan kausal antarvariabel melalui pengujian hipotesis (Effendi, 2012:5).

Penelitian ini memiliki 24 indikator pernyataan yang diolah sesuai dengan dimensi yang membentuk masing-masing variabel.penelitian ini mempunyai tiga variabel, yang pertama adalah word of mouth yang di dalamnya terdapat 9 indikator dalam membentuk dimensinya. Selanjutnya online review customer memiliki 6 indikator yang membentuk dimensinya. Variabel terakhir yaitu kualitas informasi yang di dalamnya terdapat 10 indikator yang membentuknya.

Metode survei adalah metode yang digunakan dalam penelitian ini yaitu dengan cara menyebarkan kuesioner secara online kepada banyak pihak. Kuesioner yaitu serangkaian atau daftar pertanyaan yang telah disusun secara sistematis untuk dijawab oleh responden (Ardianto, 2014:162). Penulis akan menggunakan Skala Likert sebagai skala pengukuran. Skala Likert dapat dipakai untuk menilai sikap, pendapat dan persepsi seseorang atau sekelompok orang tentang fenomena sosial. Kuesioner ini akan penulis sebarkan kepada responden yaitu mahasiswa aktif DKI Jakarta, penulis akan menyebarkan kuesioner secara langsung melalui google form kepada mahasiswa aktif di DKI Jakarta sebanyak 100 responden. Untuk mendapati kuesioner tersebut sudah reliabel maka dilakukan pengujian reliabilitas kuesioner dengan bantuan program komputer SPSS 22.0. 


\section{Hasil Temuan dan Diskusi}

Uji Validitas kuesioner menunjukkan setiap pernyataan dari variabel $\mathrm{X}$ dan $\mathrm{Y}$ dapat dikatakan valid, karena nilai dari corrected item total correlation $>$ dari patokannya yaitu 0.2 . Kemudian dilakukan juga uji reliabilitas sebagai berikut.

\section{Uji Reliabilitas}

Tabel 1. Uji Reliabilitas

\begin{tabular}{|c|c|c|}
\hline Variabel & Cronbach's Alpha & Keterangan \\
\hline E-Wom (X1) & 0,723 & Reliabel \\
\hline Online Customer Review & 0,784 & Reliabel \\
(X2) & & \\
\hline Kualitas Informasi (X3) & 0,773 & Reliabel \\
\hline Minat Beli(Y) & 0,802 & Reliabel \\
\hline
\end{tabular}

Sumber: Data Pengolahan SPSS Versi 22

Dari Tabel 2 dapat diketahui nilai Cronbach's Alpha dari Variabel E-Wom, Online Customer Review, Kualitas Informasi, dan Minat Beli melebihi 0,6 oleh sebab itu item tersebut Reliabel.

\section{Uji Multikolinieritas}

Tabel 2. Hasil Uji Multikolinieritas Coefficients $^{8}$

\begin{tabular}{|c|c|c|c|}
\hline \multirow[b]{2}{*}{ Mode } & & \multicolumn{2}{|c|}{ Collinearity Statistics } \\
\hline & & Tolerance & VIF \\
\hline \multirow[t]{4}{*}{1} & (Constant) & & \\
\hline & Total_EWom & .565 & 1,771 \\
\hline & Total_OnlineCustomerReview &, 558 & 1,793 \\
\hline & Total_KualitasInformasi & 540 & 1,852 \\
\hline
\end{tabular}

Sumber: Data Pengolahan SPSS Versi 22

Dari tabel 3 yaitu tidak adanya variabel independen yang mempunyai nilai VIF (Variance Inflation Factor) $>10$, dan tidak ada variabel independen yang memiliki nilai (TOL) Tolerance $<0,10$ oleh sebab itu bisa disimpulkan bahwa tidak adanya multikolonieritas antar variabel independen dalam model regresi. 
Julian Andrew, Rezi Erdiansyah: Analisis Pengaruh E-WOM, Online Review, dan Kualitas Informasi terhadap Minat Beli di Market Place Tokopedia

\section{Uji Normalitas}

Tabel 3. Hasil Uji Normalitas Kolmogorov-Smirnov Test

\begin{tabular}{|c|c|c|}
\hline & & Unstandardized Residual \\
\hline $\mathrm{N}$ & & 100 \\
\hline \multirow[t]{2}{*}{ Normal Parameters $\mathrm{a}, \mathrm{b}$} & Mean & .0000000 \\
\hline & Std. Deviation & 49026122 \\
\hline \multirow[t]{3}{*}{ Most Extreme Differences } & Absolute & .099 \\
\hline & Positive & 060 \\
\hline & Negative &,- 099 \\
\hline Test Statistic & & 099 \\
\hline Asymp. Sig. (2-tailed) & &, $054^{c}$ \\
\hline
\end{tabular}

Sumber: Data Pengolahan SPSS Versi 22

Dari Tabel 4 diatas dapat terlihat bahwa nilai signifikansi sebesar 0,054 yang berarti $>$ dari 0,05 sehingga dapat disimpulkan bahwa data yang diuji berdistribusi normal.

\section{Uji Heteroskedastisitas}

Tabel 4. Hasil Uji Heteroskedastisitas

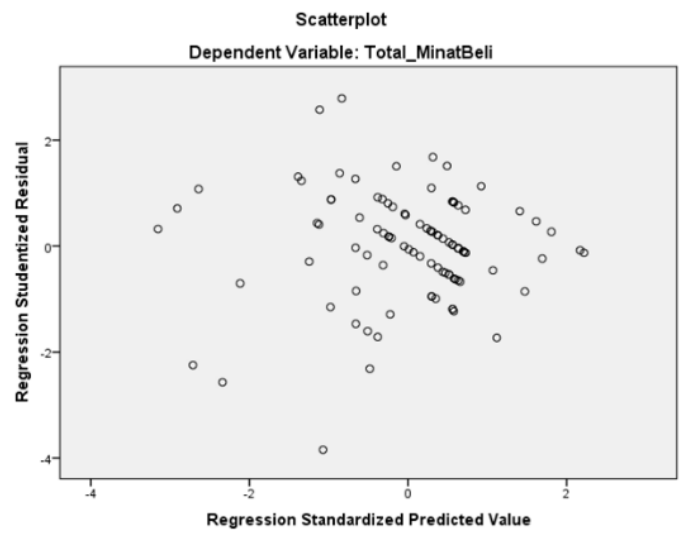

Sumber: Data Pengolahan SPSS Versi 22

Pada grafik scatterplot di atas, tidak adanya pola yang jelas dan titik-titik yang menyebar di atas dan di bawah angka 0 pada sumbu Y, maka sebab itu bisa diambil kesimpulan data dalam penelitian tidak adanya heteroskedastisitas. 


\section{Uji T (Parsial)}

Tabel 5. Hasil Uji T (Parsial)

Coefficients $^{2}$

\begin{tabular}{|c|c|c|c|c|c|}
\hline \multirow[b]{2}{*}{ Model } & \multicolumn{2}{|c|}{$\begin{array}{c}\text { Unstandardized } \\
\text { Coefficients }\end{array}$} & \multirow{2}{*}{\begin{tabular}{|c|} 
Standardized \\
Coefficients \\
Beta \\
\end{tabular}} & \multirow[b]{2}{*}{$\mathrm{t}$} & \multirow[b]{2}{*}{ Sig. } \\
\hline & B & Std. Error & & & \\
\hline $\begin{array}{l}\text { (Constant) } \\
\text { Total_EWom }\end{array}$ & $\begin{array}{l}-, 812 \\
, 313\end{array}$ & $\begin{array}{l}., 537 \\
.160\end{array}$ & 192 & $\begin{array}{l}-1,511 \\
1,952\end{array}$ & $\begin{array}{l}, 134 \\
, 054\end{array}$ \\
\hline $\begin{array}{c}\text { Tota1_OnlineCustome } \\
\text { rReview } \\
\text { Total_KualitasInform } \\
\text { asi }\end{array}$ &, 328 & ,146 &, 372 & 3,703 & . \\
\hline
\end{tabular}

Sumber: Data Pengolahan SPSS Versi 22

Dari tabel 6 variabel E-WOM memiliki nilai sig. 0,054 >0,05. Oleh sebab itu $\mathrm{H} 0$ diterima dan Ha ditolak karena itu E-WOM secara parsial tidak memiliki pengaruh terhadap Minat Beli pada Tokopedia. Variabel Online Customer Review memiliki nilai sig. $0,019<0,05$. Sehingga $\mathrm{H} 0$ ditolak dan Ha diterima maka secara parsial Online Customer Review memiliki pengaruh Minat Beli pada Tokopedia. Variabel Kualitas Informasi memiliki nilai sig. 0,000 > 0,05. Sehingga H0 ditolak dan Ha diterima karena Kualitas Informasi secara parsial dapat memberi pengaruh Minat beli pada Tokopedia.

\section{Uji Koefisien Determinasi}

Tabel 6. Uji Koefisien Determinasi

Model Summary ${ }^{\mathrm{b}}$

\begin{tabular}{|c|c|c|c|c|}
\hline Model & R & R Square & Adjusted R Square & $\begin{array}{l}\text { Std. Error of the } \\
\text { Estimate }\end{array}$ \\
\hline 1 &, $690^{8}$ &, 476 &, 460 &, 4979 \\
\hline
\end{tabular}

Sumber: Data Pengolahan SPSS Versi 22

Berdasarakan tabel 7 terlihat bahwa koefisien determinasi dari R (adjusted Rsquare) yang dihasilkan yaitu sebesar 0,460 atau 46\% yang berarti E-WOM, Online Customer Review, dan Kualitas Informasi adalah variabel-variabel bebas yang bisa memberikan pengaruh pada variabel terikat yaitu Minat Beli sebesar 46\%. Sementara sisanya sebesar 54\% dipengaruhi oleh faktor-faktor lainnya yang tidak diteliti pada penelitian ini. 


\section{Uji Analisis Linear Berganda}

Tabel 7. Hasil Uji Analisis Linear Berganda Coefficients $^{\mathrm{a}}$

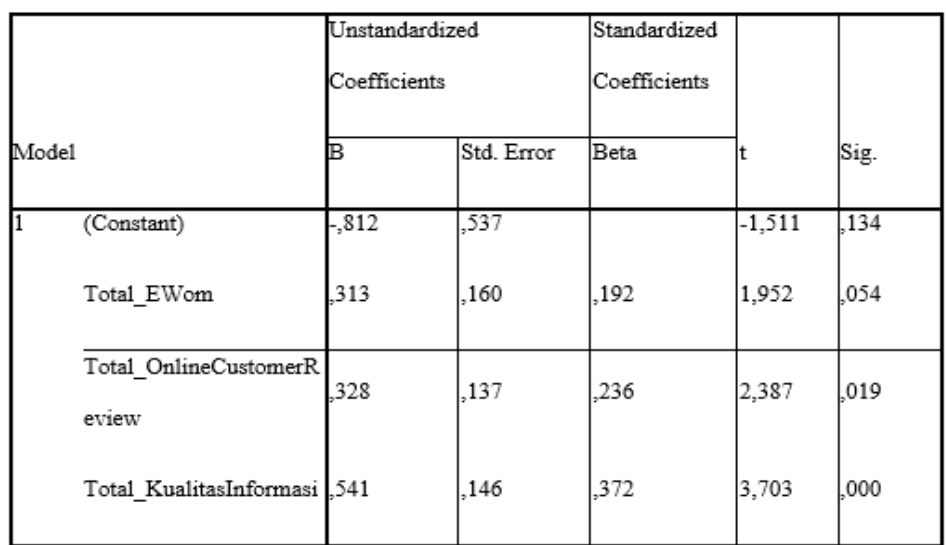

Sumber: Data Pengolahan SPSS Versi 22

Berdasarkan hasil persamaan regresi berganda diatas dapat diketahui bahwa:

- Nilai konstanta $(\alpha)$ sebanyak -0,812. dari hasil tersebut membuktikan bahwa terjadi hubungan yang searah antara E-Wom, Online Review, Kualitas Informasi dengan Minat Beli . Artinya apabila E-Wom, Online Review, Kualitas Informasi bernilai 0 maka diperkirakan Minat Beli akan meningkat sebesar 0,812.

- Koefisien Regresi Variabel E-Wom terhadap Minat Beli, sebanyak -0,313. Ini membuktikan adanya hubungan yang terbalik antara variabel minat beli dan EWom. Jika E-Wom mendapati kenaikan satu satuan, maka Minat Beli akan mendapati penurunan sebesar 0,313 dengan asumsi bahwa variabel Online Review dan Kualitas Informasi dalam kondisi tetap atau konstan.

- Koefisien Regresi Variabel Online Review terhadap Kepuasan nasabah, sebanyak 0,328 . Ini membuktikan bahwa, adanya hubungan yang searah antara variabel Online Review dan Minat Beli. Jika Online Review mendapati kenaikan satu satuan, maka Minat Beli akan mendapati peningkatan sebanyak 0,328 dengan asumsi bahwa variabel E-Wom, dan Kualitas Informasi dalam kondisi tetap atau konstan.

- Koefisien Regresi Variabel Kualitas Informasi terhadap Minat Beli, sebesar 0,541. Ini membuktikan bahwa, adanya hubungan yang searah antara variabel Kualitas Informasi dan Minat Beli. Jika Kepercayaan mendapati kenaikan satu satuan, maka Minat Beli mendapati peningkatan sebesar 0,541 dengan asumsi bahwa variabel EWom, dan Online Review dalam kondisi tetap atau konstan.

\section{Simpulan}

Berdasarkan hasil penelitian dan pembahasan yang telah di lakukan oleh peneliti, maka peneliti menarik kesimpulan bahwa e-WOM (X1) tidak berpengaruh signifikansi pada minat beli (Y), Online Review (X2) tidak berpengaruh signifikansi pada minat beli (Y), dan Kualitas Informasi (X3) berpengaruh signifikansi pada minat beli (Y). 


\section{Ucapan Terima Kasih}

Terima kasih penulis haturkan kepada Fakultas Ilmu Komunikasi Universitas Tarumanagara yang telah memberikan kesempatan penerbitan artikel jurnal ini. Ucapan Terima kasih juga saya haturkan kepada orang tua, saudara, kerabat, dan responden yang telah memberikan dukungan dan bantuannya kepada penulis.

\section{Daftar Pustaka}

Ardianto, Elvinaro. (2014). Metodologi Penelitian untuk Public Relations Kuantitatif dan Kualitatif. Bandung: Simbiosa Rekatama Media.

Bungin, Burhan. (2013). Metode Penelitian Kuantitatif. Jakarta: Prenadamedia.

Effendi, Sofian. (2012). Metode Penelitian Survei. Jakarta: LP3ES

Evans, Dave and Jake Mckee. (2010). Sosial Media Marketing. Indiana polis: Wiley Publishing, Inc.

Paramita, E.L., \& Wijaya, Tomi. (2014). Pengaruh Electronic Word Of Mouth (Ewom) Terhadap Keputusan Pembelian Kamera Dslr. Jurnal Ilmiah, 2, 13. Terarsip di: https://publikasiilmiah.ums.ac.id/bitstream/handle/11617/4729/3Pengaruh\%20El ectronic $\% 20$ Word $\% 20$ of $\% 20$ Mouth $\% 20$ terhadap $\% 20 \mathrm{keputusan} \% 20$ pembelian \%20kamera\%20DSLR-

Tommi\%20Wijaya\%20dan\%20Eristia\%20Lidia\%20Paramita\%20(1219).pdf?sequence $=1$

Suwardi, \& dkk. (2016). Pengaruh Electronic Word Of Mouth Terhadap Citra Destinasi Serta Dampaknya Pada Minat Dan Keputusan Berkunjung (Survei pada Followers Aktif Akun Instagram Indtravel yang Telah Mengunjungi Destinasi Wisata di Indonesia). Jurnal Administrasi Bisnis, 2, 3-4. Terarsip di: https://media.neliti.com/media/publications/87189IDpengaruhelectronicwordof mouth-terhad.pdf

Wibawa, B.M., \& dkk. (2016). Pengaruh Online Customer Review dan Rating Terhadap Kepercayaan dan Minat Pembelian pada Online Marketplace di Indonesia. Jurnal Teknik ITS, 2, A165. Terarsip di: http://ejurnal.its.ac.id/index.php/teknik/article/viewFile/19671/2853 